\title{
Composition and distribution of dissolved carbohydrates in the Beaufort Sea Mackenzie margin (Arctic Ocean)
}

\author{
Christos Panagiotopoulos ${ }^{\mathrm{a}, *}$, Richard Sempéré ${ }^{\mathrm{a}}$, Violaine Jacq ${ }^{\mathrm{b}}$, Bruno Charrière ${ }^{\mathrm{a}, \mathrm{c}}$ \\ a Aix-Marseille Université, Mediterranean Institute of Oceanography (MIO), 13288, Marseille, Cedex 9, Université de Toulon, 83957, CNRS-INSU/IRD UM 110, France \\ ${ }^{\mathrm{b}}$ Université Pierre et Marie Curie, Laboratoire d'Océanographie et du climat: Expérimentations et approches Numériques (LOCEAN), CNRS-INSU/IRD/IPSL, 75005 Paris, France
}

' Université de Perpignan Via Domitia, Centre de Formation et de Recherche sur les Environnements Méditerranéens (CEFREM), UMR 5110, 66860 Perpignan, France

\section{A R T I C L E I N F O}

\section{Article history:}

Received 31 July 2014

Received in revised form 11 September 2014

Accepted 16 September 2014

Available online 5 October 2014

\section{Keywords:}

Dissolved organic carbon (DOC)

Dissolved carbohydrates (TDCHO)

Mackenzie River margin

Distribution and origins of carbohydrates

Beaufort Sea

\begin{abstract}
A B S T R A C T
The carbohydrate composition (TDCHO) of dissolved organic matter (DOM) was studied in the Mackenzie margin (southeast Beaufort Sea) in summer 2009 as a part of the MALINA project. Sampling was performed in the shelf (bottom depth $\leq 100 \mathrm{~m}$ ), slope $(100 \mathrm{~m}<$ bottom depth $\leq 1000 \mathrm{~m}$ ), and basin (bottom depth $>1000 \mathrm{~m}$ ) areas of the Mackenzie margin. Our results showed that sugar concentrations did not follow dissolved organic carbon (DOC) patterns, which decreased from shelf to basin stations (from 115 to $65 \mu \mathrm{M}$ ), but instead remained rather constant (965-900 nM), indicating an accumulation of carbohydrates in surface waters (0-80 m). TDCHO concentrations exhibited their highest values (>1000 nM) and higher relative abundance to DOC in the central sector of the studied area, especially in the zone between 130 and $135^{\circ} \mathrm{W}$ indicating differences in their distribution in the broader area and possible various sources. TDCHO represented $6 \pm 2 \%$ and $8 \pm 3 \%$ of DOC (TDCHO-C/DOC) for the shelf and basin stations, respectively. Semi-labile DOC estimated values accounted for $10-40 \%$ and $20-50 \%$ of DOC in the slope and basin areas and agreed well with the above TDCHO/DOC values suggesting a gradient of carbohydrate freshness from inshore to offshore stations. The high fucose + rhamnose relative abundances (Fuc. + Rha. 15-18\%) and high C/N ratios (19-13) recorded in the surface waters of the shelf area are indicative of soil-derived matter delivered by the Mackenzie River, possibly with contributions from mainly gymnosperm terrestrial plants. The high abundance of glucose (up to 50\%) suggests that the carbohydrate component of the DOM in the Mackenzie margin appears to have a more pronounced marine autochthonous origin with an important contribution of terrestrial sources, especially for the shelf stations. Overall, these results suggest a largely uniform distribution of TDCHO carbohydrates within the area with occasional patches of lower concentrations.
\end{abstract}

\section{Introduction}

The Arctic Ocean is considered an important site of deep-water formation in the Northern Hemisphere because it actively contributes to the global thermohaline circulation and consequently, it plays an important role to the vertical flux of dissolved organic matter (DOM) (Anderson, 2002). Despite its low volume and surface compared with other oceans ( $1 \%$ of the global ocean volume), the Arctic Ocean receives the highest amount of terrestrial input in terms of freshwater discharges of particulate organic matter (POM) and DOM (POM + DOM 0.22-0.336 GT C $y^{-1}$; Dittmar and Kattner, 2003). Therefore, it is unsurprising that DOC values recorded nearshore on the Arctic continental shelf are among the highest in the world $(\sim 100 \mu \mathrm{M}$; Rich et al., 1997; Wheeler et al., 1997; Skoog et al., 2001).

Although numerous rivers enter into the Arctic Ocean, the four most important in terms of discharges are the Ob, Yenisey, and Lena from Siberia, and the Mackenzie from North America. For a long time it was

\footnotetext{
* Corresponding author.

E-mail address: christos.panagiotopoulos@mio.osupytheas.fr (C. Panagiotopoulos).
}

supposed that this terrigenous organic matter (DOM + POM) delivered by rivers was refractory compared with the organic matter freshly produced in the Arctic shelf and basin (de Leeuw and Largeau, 1993; Peulvé et al., 1996; Macdonald et al., 1998; Fernandes and Sicre, 2000). Nevertheless, recent studies in this area based on lipid biomarker analysis (Rontani et al., 2012a,b), compound specific isotopes (Drenzek et al., 2007), and ${ }^{228} \mathrm{Ra} /{ }^{226} \mathrm{Ra}$ isotopes (Hansell et al., 2004; Letscher et al., 2011 ) indicate that this material "disappears" rapidly via abiotic or biotic processes. In line with these results, bulk $\Delta^{14} \mathrm{C}$ and lignin-phenol data on Arctic riverine DOM suggested that this terrestrial material exhibits modern radiocarbon ages (Benner et al., 2004; Amon et al., 2012).

The chemical composition of the Arctic rivers has been well documented in the literature in terms of amino acids (Lara et al., 1998; Amon and Meon, 2004; Unger et al., 2005), sugars (Amon and Benner, 2003; Dittmar and Kattner, 2003; Unger et al., 2005), and lipids (Goñi et al., 2000; Zou et al., 2006; van Dongen et al., 2008). However, much less is known about the sources, distribution, and bioavailability of these compounds in the Arctic Ocean. Previous studies have indicated that in the Arctic Ocean freshly produced organic matter has high turnover rates and is labile; however, these rates of production and 
consumption differ between the different areas of the Arctic because they are closely linked to the biogeochemical characteristics of each site (Rich et al., 1997; Cottrell et al., 2006; Kirchman et al., 2009; Ortega-Retuerta et al., 2012). For example, the Chukchi and Beaufort Seas, both belonging to the western Arctic Ocean, exhibit different productivities, receive different amounts of nutrients, and experience different effects from rivers (Hill and Cota, 2005; Carmack and Wassmann, 2006; Grebmeier et al., 2006; Lavoie et al., 2009). In addition, the quantity and quality of DOM in both areas appear quite different in terms of dissolved organic carbon (DOC) content (Fransson et al., 2001; Mathis et al., 2005), chromophoric-DOM properties (CDOM; Guéguen et al., 2005; Matsuoka et al., 2012), optical characteristics including fluorescence (Osburn et al., 2009; Para et al., 2013), and amino acid content (Shen et al., 2012). However, the quality and bioavailability of organic matter cannot be evaluated fully if additional measurements of other "labile" organic compounds (e.g. carbohydrates) are not taken into account.

Currently, there is a paucity of data regarding the carbohydrate component of DOM in the Arctic Ocean. Previous investigations have reported bulk carbohydrate measurements in the Chukchi Sea (Wang et al.,
2006), but almost no carbohydrate data exist for the Beaufort Sea, into which the Mackenzie River discharges (Amon and Benner, 2003). Interestingly, the Beaufort Sea could be considered as an example of a shelf region with a large riverine input and narrow shelf, characterized by short transport times for the injection of terrestrially-derived organic matter into deeper waters (Macdonald et al., 1998; Davis and Benner, 2005; Mathis et al., 2007; Lalande et al., 2009). Therefore, the Beaufort Sea might serve as a model system for future climate scenarios in the Arctic Ocean, in which several features are currently observed. These features include (a) the increase in river runoff, (b) increase in UV radiation, (c) permafrost thawing, and (d) decrease in ice cover (Peterson et al., 2002; Grigoriev et al., 2004; Stroeve et al., 2005; Rawlins et al., 2010; Long and Perrie, 2013; Fichot et al., 2013). Therefore, the chemical characterization of the autochthonous and allochthonous components of Arctic-DOM appears critical, not only with regard to the evaluation of their relation with the sources and cycling pathways, but also with regard to the comprehension of the Arctic system evolution.

The MALINA (Mackenzie Light aNd cArbon) cruise was conducted in the Beaufort Sea in 2009 with the objectives assessing the impact of climate changes on the fate of terrestrially-derived organic carbon

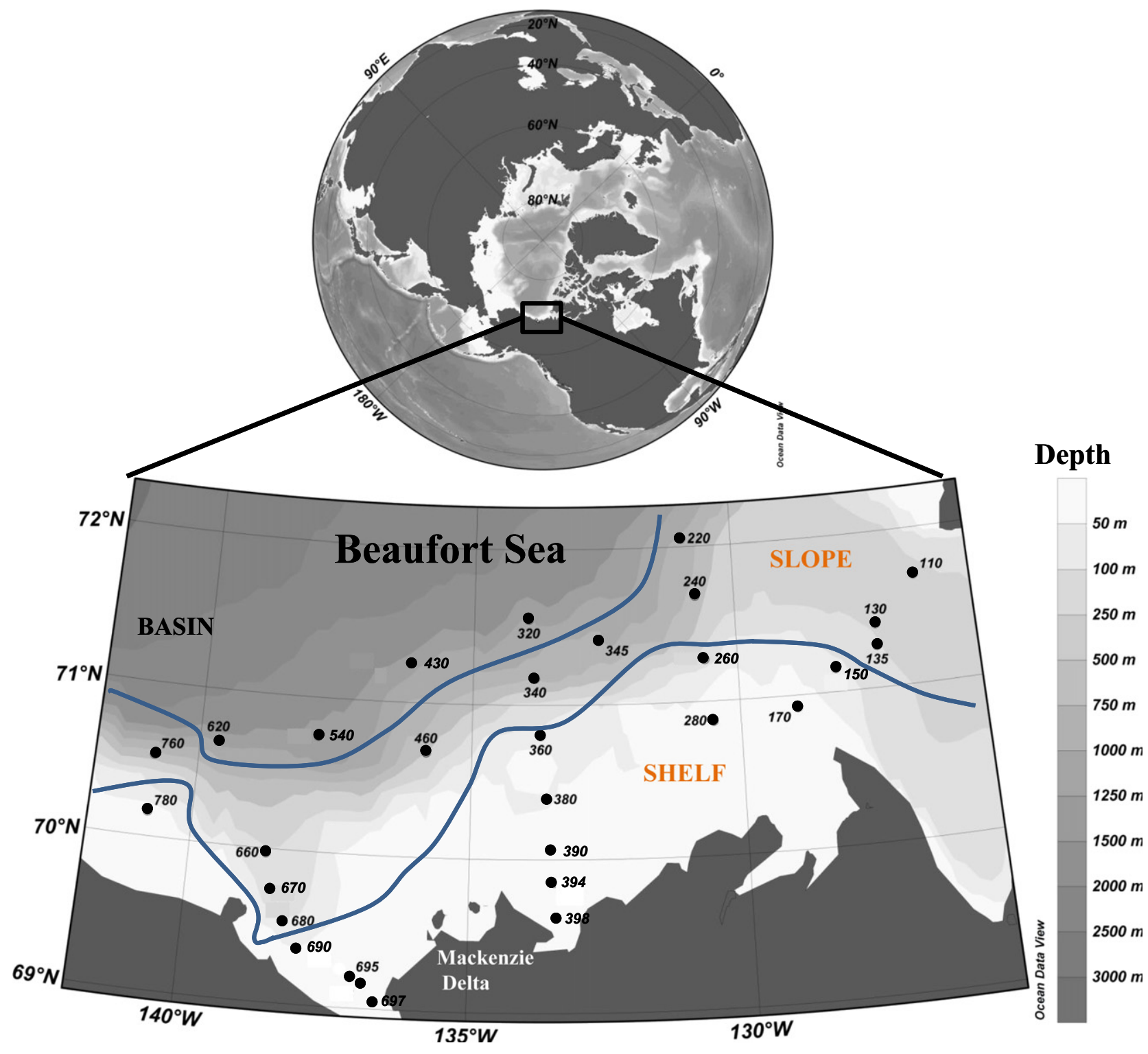


exported to the Arctic Ocean, bacterial biodiversity and the photosynthetic production of organic carbon. Here, we report the first individual dissolved carbohydrate concentrations in the Beaufort Sea together with carbohydrate values of the Mackenzie River plume. Using these data we monitored the spatial variation of the DOM carbohydrate component from the river plume (continental shelf) to the limits of its extension (continental slope-Beaufort Sea basin). Finally, based on specific monosaccharide ratios, we evaluated the major sources of organic matter (terrestrial vs marine) and degradation mechanisms occurring within the area. In this study, the objectives were as follows:

(a) to study the spatial distribution of the carbohydrate component of DOM in the Beaufort Sea and its adjacent area (continental shelf and slope affected by the discharge of the Mackenzie River);

(b) to evaluate the degradation status of DOM using DOM-yields of total carbohydrates;

(c) to examine the source and fate of DOM in the Beaufort Sea based on its carbohydrate component.

\section{Materials and methods}

\subsection{Study area}

The Canadian shelf of the southeast Beaufort Sea occupies an area of $\sim 63,000 \mathrm{~km}^{2}$, receives an annual freshwater input from the Mackenzie River of $330 \mathrm{~km}^{3}$ and for a large part of the year, it is covered by sea ice (Macdonald et al., 1999; Carmack et al., 2004). Primary productivity increases significantly (about 3-5 times higher) from the river plume to the more productive area beyond the plume (Carmack and Wassmann, 2006). Freshwater discharge by the Mackenzie River varies greatly during the year and generally peaks in summer (June-August) with values reaching as high as $25,000 \mathrm{~m}^{3} \mathrm{~s}^{-1}$ (O'Brien et al., 2006). This freshwater input has an important effect on the physical characteristics of the southern Beaufort Sea, because it maintains the strong thermohaline gradient that is responsible for the basin's surface water stratification. In terms of particle inputs, the Mackenzie River delivers the highest amount of sediment $125 \times 10^{9} \mathrm{~kg} \mathrm{yr}^{-1}$ and POC (1.8-2.1 $\times$ $10^{9} \mathrm{~kg} \mathrm{yr}^{-1}$ ) compared with other Arctic rivers (Dittmar and Kattner, 2003; Rachold et al., 2004). The annual flux of DOC of the Mackenzie River exhibits similar values to POC $\left(\sim 1.04-1.76 \times 10^{9} \mathrm{~kg} \mathrm{yr}^{-1}\right.$; Raymond et al., 2007; Holmes et al., 2012). The Mackenzie River almost exclusively drains the Canadian side of North America, where as much as $\sim 2 / 3$ of the DOM delivered to the continental shelf is rapidly mineralized in the coastal zone, compared with the much smaller ( 30\%) amount of DOM delivered to the Eurasian shelf (Hansell et al., 2004). During this open-water study period, the Mackenzie River discharge was $\sim 12,000 \mathrm{~m}^{3} \mathrm{~s}^{-1}$ (http://www.ec.gc.ca/rhc-wsc/), the coastal area was characterized by an unusual extent of ice cover, and the weather was predominately overcast.

\subsection{Sampling}

Seawater collection was undertaken within the framework of the MALINA project in the southeast Beaufort Sea from July 30 to August 27, 2009, onboard the icebreaker CCGS Amundsen. The sampling stations were distributed along seven transects with increasing numbers from north to south covering the Mackenzie plume and the broader continental shelf area (Fig. 1). To compare our results with previously obtained data on amino acids from the same area (Shen et al., 2012), the sampling stations were categorized into shelf (bottom depth $\leq$ $100 \mathrm{~m}, \mathrm{~S} \geq 27 \mathrm{psu})$, slope $(100 \mathrm{~m}<$ bottom depth $\leq 1000 \mathrm{~m})$, and basin (bottom depth $>1000 \mathrm{~m}$ ) areas. As in Shen et al. (2012), the surface water layer of the slope and basin regions was defined as 0-80-m depth (Table 1).

In total, 29 stations were sampled using Niskin bottles equipped with O-rings and silicon tubes to avoid chemical contamination. For DOC and TDCHO determinations, samples were transferred from the Niskin bottles through a Polycap AS 75 (Whatman ${ }^{\circledR}$ ) $0.2-\mu$ m nylon filter membrane cartridge into $10-\mathrm{mL}$ glass ampoules (Wheaton ${ }^{\circledR}$ ) and 40-mL Falcon vials (previously cleaned with $10 \%$ of $\mathrm{HCl}$ and Milli-Q water), respectively. Prior to sampling, the glass ampoules and falcon vials were rinsed three times with the respective sample volume, while Polycap cartridges were washed successively with $5 \%$ of $\mathrm{HCl}$, Milli-Q water, and 4-5 L of seawater before sampling (Para et al., 2013). For each sample, a new cartridge was used. In general, duplicate seawater samples were collected for both DOC and TDCHO analyses. For DOC analysis, the samples were acidified onboard with $20 \mu \mathrm{L} \mathrm{H}_{3} \mathrm{PO}_{4}$ (85\%) and then flame sealed. Finally, the DOC and TDCHO samples were stored in the dark at $4{ }^{\circ} \mathrm{C}$ and $-20{ }^{\circ} \mathrm{C}$, respectively, until laboratory analysis on land.

Shallow coastal waters were sampled using a zodiac along two transects located in the two main effluent streams of the Mackenzie River. Sampling was performed manually at the surface $(0.5-1 \mathrm{~m})$ using $5-\mathrm{L}$ clean carboys. All glassware (i.e. bottles, vials, beakers, ampoules, and pipettes) including quartz wool, used in this study for sampling and subsequent DOC and TDCHO determinations, was combusted at $450{ }^{\circ} \mathrm{C}$ for $6 \mathrm{~h}$ prior to use.

\section{Chemical analyses}

\subsection{Dissolved organic carbon (DOC) determination}

DOC concentration was measured by high-temperature combustion on a Shimadzu TOC 5000 analyzer, as described in Sohrin and Sempéré

Table 1

Average values of bulk parameters ( $\mathrm{Chl} \alpha$, DOC, and TDCHO) and physical characteristics (bathymetry and salinity) measured in the continental shelf (bottom depth $\leq 100 \mathrm{~m}$, salinity $\geq 27$ psu), slope (bottom depth 100-1000 m), and basin (bottom depth $>1000 \mathrm{~m}$ ) of the Beaufort Sea (Fig. 1). The contribution of TDCHO to the DOC pool is also given.

\begin{tabular}{|c|c|c|c|c|c|c|c|}
\hline Station & Depth (m) & Salinity (psu) & Chl $\alpha\left(\mu g \mathrm{~L}^{-1}\right)$ & $\mathrm{DOC}\left(\mu \mathrm{mol} \mathrm{L}{ }^{-1}\right)$ & TDCHO $\left(\mathrm{nmol} \mathrm{L}^{-1}\right)$ & TDCHO-C/DOC & $\begin{array}{l}\text { TDCHO-C }+ \\
\text { TDAA-C } / \text { DOC }\end{array}$ \\
\hline \multicolumn{8}{|l|}{ Shelf } \\
\hline 0-80 m & $\begin{array}{l}14 \pm 16 \\
(\mathrm{n}=24)\end{array}$ & $\begin{array}{c}25.88 \pm 8.15 \\
(n=23)\end{array}$ & $\begin{array}{l}0.44 \pm 0.25 \\
(\mathrm{n}=8)\end{array}$ & $\begin{array}{c}115.6 \pm 86.02 \\
(\mathrm{n}=24)\end{array}$ & $\begin{array}{r}965.3 \pm 361.4 \\
(\mathrm{n}=24)\end{array}$ & $\begin{array}{l}6 \pm 4 \% \\
\quad(n=24)\end{array}$ & $\begin{array}{l}7 \pm 3 \% \\
(\mathrm{n}=21)\end{array}$ \\
\hline \multicolumn{8}{|l|}{ Slope } \\
\hline 0-80 m & $\begin{array}{l}35 \pm 27 \\
(n=29)\end{array}$ & $\begin{array}{c}29.12 \pm 3.97 \\
(n=29)\end{array}$ & $\begin{array}{l}0.34 \pm 0.37 \\
(\mathrm{n}=17)\end{array}$ & $\begin{array}{r}72.9 \pm 24.2 \\
(\mathrm{n}=29)\end{array}$ & $\begin{array}{r}678.5 \pm 262.7 \\
(\mathrm{n}=29)\end{array}$ & $\begin{array}{l}6 \pm 2 \% \\
\quad(n=29)\end{array}$ & $\begin{array}{l}7 \pm 3 \% \\
(\mathrm{n}=26)\end{array}$ \\
\hline$>80 \mathrm{~m}$ & $\begin{array}{r}170 \pm 50 \\
(\mathrm{n}=8)\end{array}$ & $\begin{array}{c}33.47 \pm 0.770 \\
(\mathrm{n}=8)\end{array}$ & ND & $\begin{array}{c}58.9 \pm 2.21 \\
(\mathrm{n}=8)\end{array}$ & $\begin{array}{c}540.3 \pm 284.8 \\
(\mathrm{n}=8)\end{array}$ & $\begin{array}{l}5 \pm 3 \% \\
\quad(n=8)\end{array}$ & $\begin{array}{l}7 \pm 3 \% \\
(n=8)\end{array}$ \\
\hline \multicolumn{8}{|l|}{ Basin } \\
\hline 0-80 m & $\begin{array}{l}35 \pm 33 \\
(\mathrm{n}=10)\end{array}$ & $\begin{array}{c}28.47 \pm 3.36 \\
(\mathrm{n}=10)\end{array}$ & $\begin{array}{l}0.19 \pm 0.22 \\
(n=10)\end{array}$ & $\begin{array}{c}65.1 \pm 10.4 \\
(\mathrm{n}=10)\end{array}$ & $\begin{array}{r}899.5 \pm 321.3 \\
(\mathrm{n}=10)\end{array}$ & $\begin{array}{l}8 \pm 3 \% \\
\quad(n=10)\end{array}$ & $\begin{array}{c}10 \pm 3 \% \\
\quad(n=8)\end{array}$ \\
\hline$>80 \mathrm{~m}$ & $\begin{array}{c}516 \pm 575 \\
(\mathrm{n}=12)\end{array}$ & $\begin{array}{c}34.15 \pm 0.718 \\
\quad(n=12)\end{array}$ & ND & $\begin{array}{r}53.4 \pm 3.33 \\
(\mathrm{n}=12)\end{array}$ & $\begin{array}{r}464.9 \pm 91.74 \\
(\mathrm{n}=12)\end{array}$ & $\begin{array}{l}5 \pm 1 \% \\
\quad(\mathrm{n}=12)\end{array}$ & $\begin{array}{l}6 \pm 1 \% \\
(\mathrm{n}=8)\end{array}$ \\
\hline
\end{tabular}

ND: no data.

a Total dissolved amino acid (TDAA) data are from Shen et al. (2012). 
(2005) and Para et al. (2013) A four-point calibration curve was constructed daily using standards prepared by diluting a stock solution of potassium hydrogen phthalate in Milli-Q water. To avoid random errors associated with day-to-day instrument variability, all samples from a given experiment were analyzed in a single day. The procedural blanks (i.e., runs with Milli-Q water) ranged from 1 to $2 \mu \mathrm{M} \mathrm{C}$ and were subtracted from the values presented here. Deep seawater reference samples (provided by D. Hansell, Univ. of Miami) were run daily ( $43.5 \mu \mathrm{M} \mathrm{C}, \mathrm{n}=4$ ) to check the accuracy of the DOC analysis.

\subsection{Total dissolved carbohydrate (TDCHO) determination}

\subsubsection{Carbohydrate extraction and isolation}

Aliquots of 6-8 mL were desalted using dialysis tubes with a molecular weight cut-off of 100-500 Da (Spectra/Por ${ }^{\circledR}$ Biotech cellulose ester) (Engel and Handel, 2011). Prior to use, the dialysis tubes were rinsed with Milli-Q water to remove sodium azide. Before applying the sample, the interior of the tube was rinsed three times with 4-5 mL of Milli-Q water and then with an aliquot (1-2 mL) of the sample. The dialysis tube was then filled with $8 \mathrm{~mL}$ of the sample and dialysis conducted into a 1-L beaker filled with Milli-Q water at $4{ }^{\circ} \mathrm{C}$ in the dark. Dialysis was achieved after $4-5 \mathrm{~h}$ (salinity dropped from 35 to $1-2 \mathrm{~g} \mathrm{~L}^{-1}$ ). Prior to sample removal, the tubes were placed into an ultrasonic bath for $5 \mathrm{~min}$. The samples were then transferred into $40-\mathrm{mL}$ Falcon vials (previously cleaned with $10 \% \mathrm{HCl}$ and Milli-Q water) frozen at $-30{ }^{\circ} \mathrm{C}$ and freeze dried. The obtained powder was hydrolyzed with $1 \mathrm{M} \mathrm{HCl}$ for $20 \mathrm{~h}$ at $100{ }^{\circ} \mathrm{C}$ and the samples were again freeze dried to remove $\mathrm{HCl}$ (Murrell and Hollibaugh, 2000; Engel and Handel, 2011). As a precaution, we ensured the complete removal of $\mathrm{HCl}$ by adding $2-3 \mathrm{~mL}$ of Milli-Q water and repeating the freeze-drying process. The dried samples were re-dissolved in $4 \mathrm{~mL}$ of Milli-Q water, filtered through quartz wool, and pipetted into scintillation vials. The vials were kept at $4{ }^{\circ} \mathrm{C}$ until the time of analysis (this never exceeded $24 \mathrm{~h}$ ). Finally, it is important to note that the current desalination procedure does not allow the determination of the dissolved free monosaccharides (i.e., sugar monomers present in samples with $\mathrm{MW} \sim 180 \mathrm{Da}$ ) because these compounds are lost/poorly recovered during the dialysis step.

\subsubsection{Liquid chromatography}

Carbohydrate concentrations in the samples were measured by HPAEC-PAD according to Mopper et al. (1992) and were modified following Panagiotopoulos et al. (2001, 2012). Briefly, neutral and amino monosaccharides were separated in an anion exchange column (CarbopacPA-1, Dionex) by isocratic elution (mobile phase $19 \mathrm{mM}$ $\mathrm{NaOH}$ ), and were detected by an electrochemical detector set in the pulsed amperometric mode (Panagiotopoulos et al., 2012). Acidic monosaccharides (uronic acids) were detected in a separate analysis using gradient conditions (Panagiotopoulos et al., 2012). The flow rate and column temperature were set at $0.7 \mathrm{~mL} \mathrm{~min}^{-1}$ and $17^{\circ} \mathrm{C}$, respectively. Data acquisition and processing were performed using the Dionex software Chromeleon.

The recovery yields of the complete procedure (dialysis and hydrolysis) were estimated using standard polysaccharides (laminarin and chondroitine sulfate) and ranged from 82 to $86 \%(n=3)$. Repeated injections ( $n=6$ ) of a dissolved sample resulted in a CV of $12-15 \%$ for the peak area for all monosaccharides. Adonitol was used as an internal standard and was recovered at a rate of $80-95 \%$; however, we have chosen not to correct our original data. TDCHO corresponded to sum of neutral, amino, and acidic monosaccharides.

\subsection{Statistics}

The Mann-Whitney $\mathrm{U}$ test (two tailed, $\alpha=0.05$ ) was used to assess the statistical differences between unequal group sizes, as previously employed in the same area by Shen et al. (2012). This approach was important in order to compare our sugar data with the data on amino acids obtained by previous authors. Statistics were performed using the statistical package XLSTAT 2010.2 (Microsoft Excel add-in program).

\section{Results}

\subsection{General observations on DOM and TDCHO characteristics}

During the study period, average DOC concentrations in the surface waters $(0-80 \mathrm{~m})$ of the Beaufort Sea Mackenzie margin varied from 115 to $65 \mu \mathrm{M}$, with higher values observed within the area of the continental shelf into which the Mackenzie River discharges (Table 1; Fig. 2A). Lower values ranging from 53 to $59 \mu \mathrm{M}$ were observed at higher depths (>80 m), which is in agreement with previous studies conducted in the same area (Emmerton et al., 2008) and/or the general DOC concentrations recorded in intermediate waters in the Arctic system (Amon and Benner, 2003). As expected, DOC concentrations decreased with depth and increasing salinity, whereas they showed different correlations with salinity in each geographical sector (shelf, slope, and basin). DOC was strongly correlated with salinity in the shelf area $\left(\mathrm{R}^{2}=0.91, \mathrm{p}<0.0001, \mathrm{n}=24\right)$, but a weaker correlation was found for the basin area $\left(R^{2}=0.68, p=0.0003, n=12\right)$, indicating conservative mixing between the shelf and basin waters, which corroborates previous studies (Dittmar and Kattner, 2003 and references therein). In the basin area, DOC concentrations generally peaked in the surface waters together with a maximum of deep chlorophyll; however, while this trend was not always observed for the shelf and slope areas, possibly reflecting the presence of both allochthonous and autochthonous organic matter.

TDCHO concentrations varied from 425 to $1766 \mathrm{nM}$ with higher average values observed on the continental shelf (Table 1; Fig. 2B). TDCHO profile concentrations closely followed DOC patterns and decreased with depth (Fig. 3). Below $80 \mathrm{~m}$, average TDCHO concentrations were 540 and $465 \mathrm{nM}$ for the slope and basin areas, respectively (Table 1). In contrast to DOC, TDCHO did not always exhibit a significant

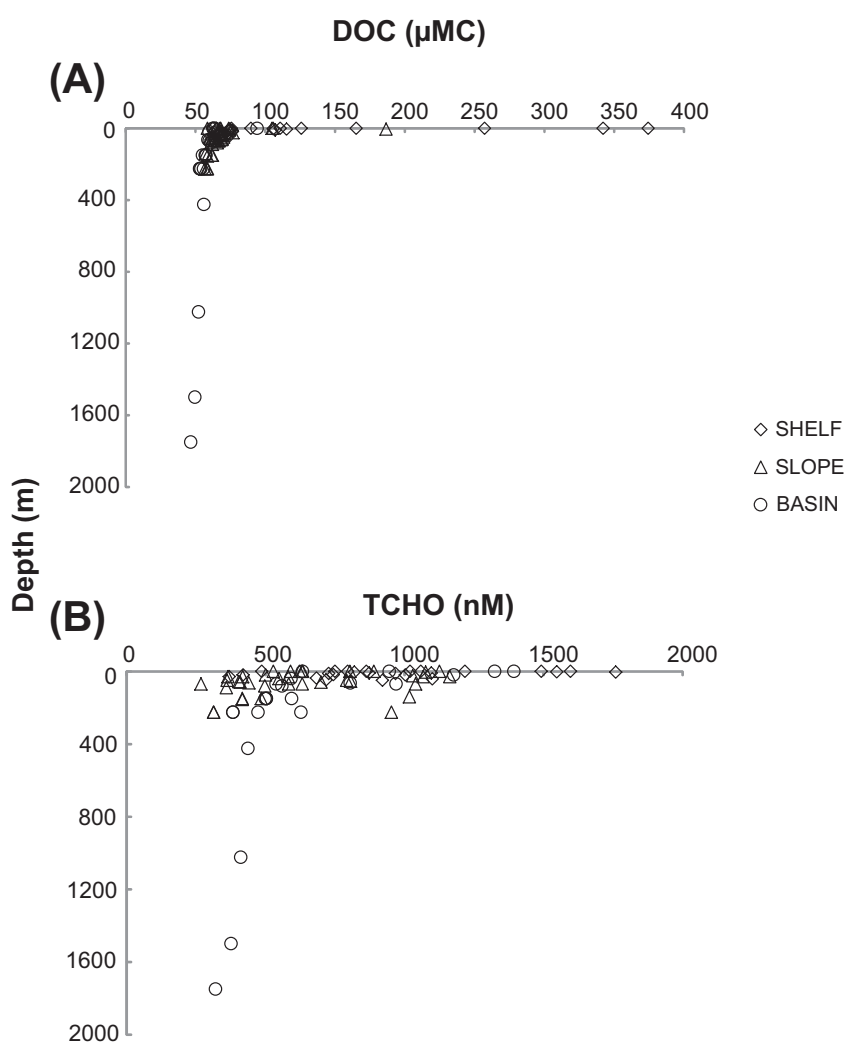

Fig. 2. Vertical profiles for the shelf, slope, and basin areas for (A) DOC and (B) TDCHO. 
relationship with salinity. As such, TDCHO did not correlate at all with salinity in the shelf area $\left(R^{2}=0.0008, p=0.8920, n=24\right)$, while significant correlations were observed for the slope $\left(R^{2}=0.189, \mathrm{p}=\right.$ $0.0057, \mathrm{n}=37)$ and basin $\left(\mathrm{R}^{2}=0.51, \mathrm{p}=0.0042, \mathrm{n}=12\right)$ areas. Our TDCHO concentrations are within the same range as previously reported for dissolved neutral sugars in the Arctic system (34-2856 nM, Rich et al., 1997; 163-1253 nM, Engbrodt and Kattner, 2005) and other oceanic regimes (128-490 nM, Skoog and Benner, 1997; 58-890 nM, Sempéré et al., 2008) including Antarctica (300-3000 nM; Kirchman et al., 2001). However, our TDCHO values are much lower and not comparable with those recorded in the western Arctic (Chukchi Sea; $750-3150 \mathrm{nM}$ ). This is because the latter values were obtained using a colorimetric technique (TPTZ), which is well known to include a much broader spectrum of carbohydrates (e.g., methylated sugars and amino sugars) in the analysis (Panagiotopoulos and Sempéré, 2005; Panagiotopoulos et al., 2013).

The contribution of TDCHO to the DOC pool (name hereafter TDCHO-C/DOC or TDCHO-yields) was higher in the surface water of the basin area $(8 \pm 3 \%, n=10)$ than the slope $(6 \pm 4 \%, n=24)$ or shelf sites (Table 1). Below $80 \mathrm{~m}$, TDCHO-yields for both slope and basin areas were $\sim 5 \%$. Similarly, as above, our values are lower than reported for the Chukchi Sea (13-20\%; Wang et al., 2006), but are in agreement with those from the Arctic system ( $<10 \%$; Rich et al., 1997) including ultrafiltrated DOM from the Arctic rivers (Amon and Benner, 2003). Interestingly enough, a similar range of TDCHO-yields (1-11\%) has been reported in the Ross Sea, Antarctica (Kirchman et al., 2001).

\subsection{TDCHO compositional patterns}

During the study period the major neutral sugar classes detected in the TDCHO pool comprised aldohexoses (glucose, mannose, and galactose), aldopentoses (arabinose and xylose), and deoxysugars (fucose and rhamnose). Charged monosaccharides such as aminosugars (glucosamine) and uronic acids (galacturonic acid) were also detected, whereas ribose (aldopentose) concentrations were below the detection limit. Aldohexoses were always the most abundant compound class (197-1456 nM; 72-82\% of TDCHO) at all sites and depths followed by aldopentoses (38-311 nM; 5-28\% of TDCHO), and deoxysugars (20-174 nM; $4-11 \%$ of TCHO). Charged monosaccharide concentrations varied from 11.4 to $110.8 \mathrm{nM}$ and represented $1-10 \%$ of TDCHO (mean $=5 \pm 2 \%, \mathrm{n}=81$ ). Glucose was the most abundant monosaccharide in all samples $(\sim 50 \%)$ followed by galactose $(\sim 18 \%)$, mannose ( $11 \%)$, and xylose ( $8 \%$ ) (Fig. 4A, B). The remaining monosaccharides contributed $<4 \%$ to the TDCHO pool. Our results indicate that the relative abundance of glucose decreased from the inshore to the offshore stations, whereas the opposite trend was observed for xylose in the surface samples ( $0-80 \mathrm{~m}$; Fig. 4A). Galactose and mannose did not seem to exhibit changes in their relative abundance in the surface samples at either the offshore or the inshore stations. As a general trend, the relative

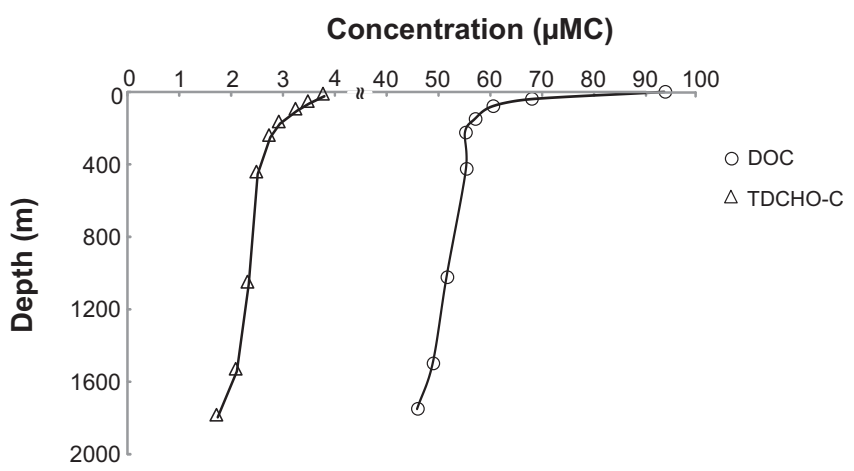

Fig. 3. Example of a typical comparison profile between DOC and TDCHO at station 620 (see Fig. 1). abundance of glucose increased with depth. Moreover, the relative abundances of most monosaccharides did not vary considerably at depths $>80 \mathrm{~m}$ between the offshore and inshore stations (Fig. 4B).

Previous investigations conducted in the Arctic Ocean have reported glucose abundances of the order of $40 \%$ in surface samples $(0-40 \mathrm{~m}$; Rich et al., 1997), whereas much lower values have been recorded for the adjacent Arctic rivers (25-28\% of TDCHO; Engbrodt, 2001). Notably, similar glucose abundances have been reported for Antarctic surface DOM samples (35-37\%; Kirchman et al., 2001). The glucose contribution to the TDCHO pool reported in this study (37-67\%) falls within the same range of values recorded in other oceanic regimes including the Pacific Ocean (Rich et al., 1996; Skoog and Benner, 1997; Sempéré et al., 2008) and the Sargasso Sea (Borch and Kirchman, 1997).

\section{Discussion}

5.1. Distribution of TDCHO in the Mackenzie River plume and the Beaufort Sea margin

Average surface DOC values in the surface layer $(0-80 \mathrm{~m})$ were higher in the western part $(230 \pm 150 \mu \mathrm{M} \mathrm{n}=4$; transect 600$)$ of the Mackenzie River plume than in the eastern part $(107 \pm 65 \mu \mathrm{M} \mathrm{n}=9$; transect 300) and they decreased from the shelf to the basin area (Figs. 5A and 6A). This feature is in agreement with previous results indicating that the river plume of elevated DOC is moving towards the east rather than the west, which is consistent with the general trend of Mackenzie River water moving towards the Canadian Archipelago in most years (Macdonald et al., 2002; Macdonald and Yu, 2006). The high DOC concentrations recorded in the shelf area most likely reflect the high amount of organic matter delivered by the Mackenzie River as well as high primary productivity (Lavoie et al., 2009; Para et al., 2013; Raimbault, unpublished data). Interestingly, the highest primary productivity value was recorded at station 398 (544 $\mathrm{mg} \mathrm{m}^{-3} \mathrm{~d}^{-1}$ ) and the lowest at station $320\left(1.34 \mathrm{mg} \mathrm{m}^{-3} \mathrm{~d}^{-1}\right)$ for the upper mixed layer (Raimbault, unpublished data).

TDCHO concentrations in surface waters $(0-80 \mathrm{~m})$ showed significant differences (Mann-Whitney U test; $\mathrm{p}<0.05, \mathrm{n}=15$ ) between the two transects and did not always follow DOC patterns (Figs. 5A and $6 \mathrm{~B}$ ). Hence, TDCHO concentrations decreased from the shelf to basin waters for the 600 transect ( $846-600 \mathrm{nM}$ ); while they remained almost stable (1190-1186 nM) for the 300 transect (Fig. 1). The low value recorded in the slope waters of the 300 transect ( $519 \mathrm{nM}$; station 340) could not be explained in this study; however, an adjacent station (345) exhibited a similar value (673 $\mathrm{nM}$ ) indicating that this result was not related to the analysis, but rather to other environmental factors (Fig. 6B). Primary production (PP) and bacterial production (BP) values did not vary significantly (PP: $\mathrm{p}=0.507, \mathrm{n}=24$; $\mathrm{BP}$ : $\mathrm{p}=0.254, \mathrm{n}=14$ ) between the two transects (i.e., 300 and 600 ). This further suggests that the accumulation of TDCHO in the surface waters in the eastern part of the river mouth cannot be explained in terms of in situ organic matter production and/or consumption.

Previous investigations have indicated that the movement of the Mackenzie River plume depends mainly on wind conditions and that easterly winds are responsible for the transport of water offshore from the continental margin (Macdonald et al., 2002; Forest et al., 2013). As shown by the salinity distribution, the western transect (i.e., 600) is affected more by the river plume (in terms of DOC) than the eastern transect (Para et al., 2013; Shen et al., 2012); however, this does not seem to be reflected in the sugar content. From a geographical point of view, the eastern transect (i.e., 300) is surrounded by more topographical features (Banks Island to the east and numerous lakes and rivers to the south between 129 and $133^{\circ} \mathrm{W}$ ) than the western part. Furthermore, during the field campaign, southeasterly winds could have caused advection of the ice pack northwards (Forest et al., 2013). This suggests that terrestrial organic matter inputs (e.g., aeolian inputs) other than from the Mackenzie River may also be an important source 


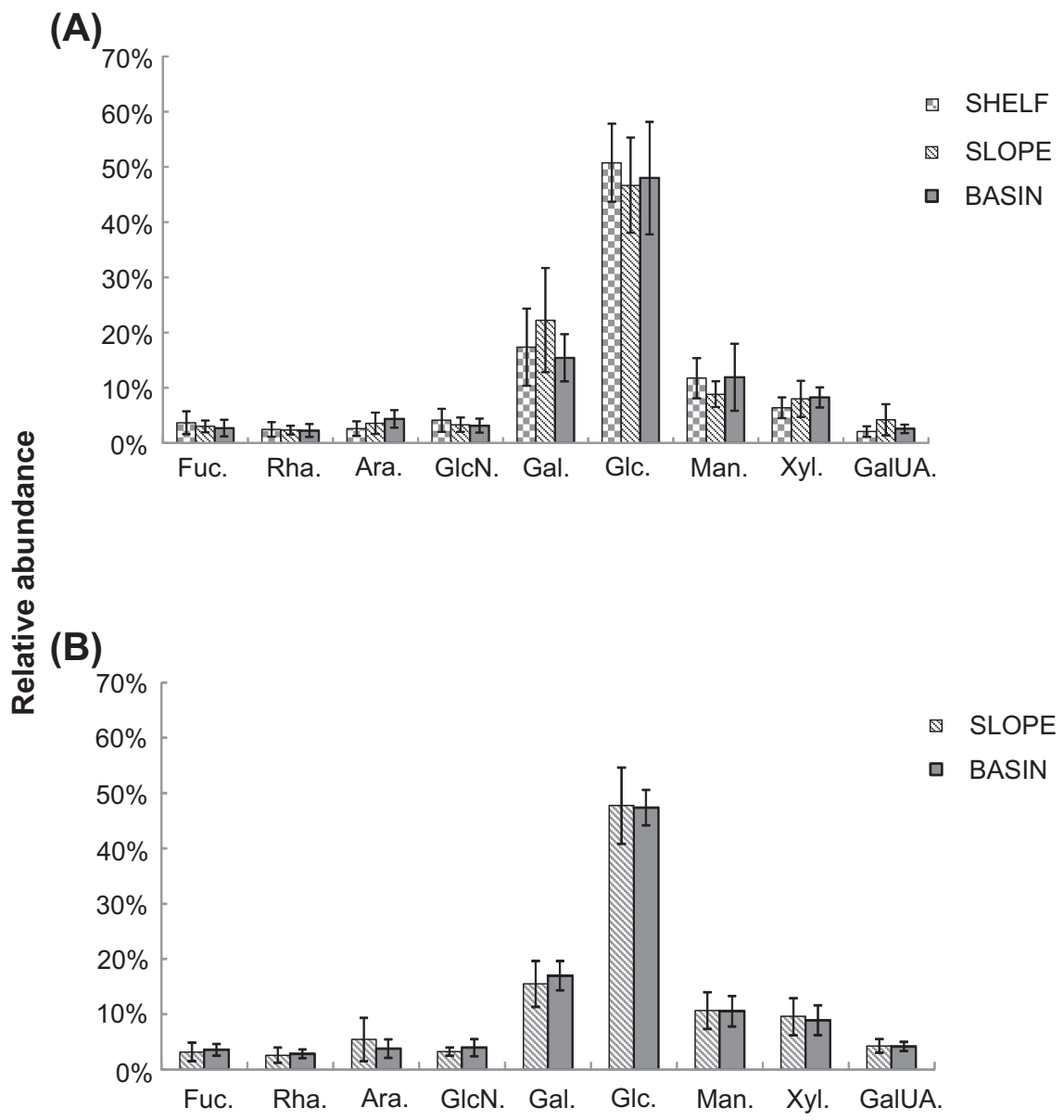

Fig. 4. Relative average abundances of dissolved monosaccharides measured in the continental shelf, slope, and basin areas of the Beaufort Sea at (A) surface ( 0 - $80 \mathrm{~m}$ ) and (B) $>80 \mathrm{~m}$. Data are given as average \pm standard deviations. Abbreviations: fucose: Fuc., rhamnose: Rha., arabinose: Ara., glucosamine: GlcN., galactose: Gal., glucose: Glc., mannose: Man., xylose: Xyl., galacturonic acid: GalUA.
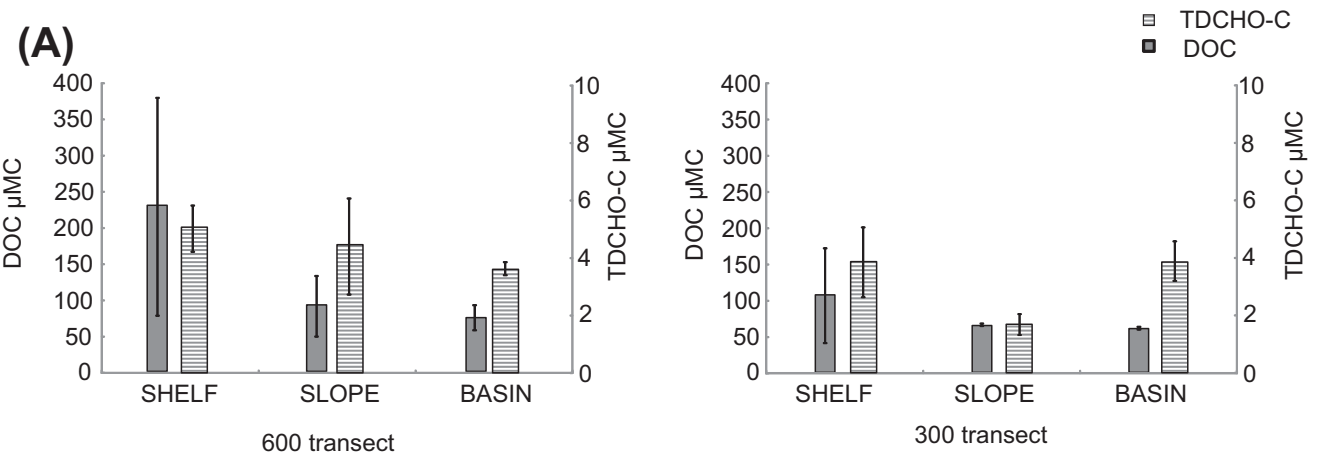

(B)
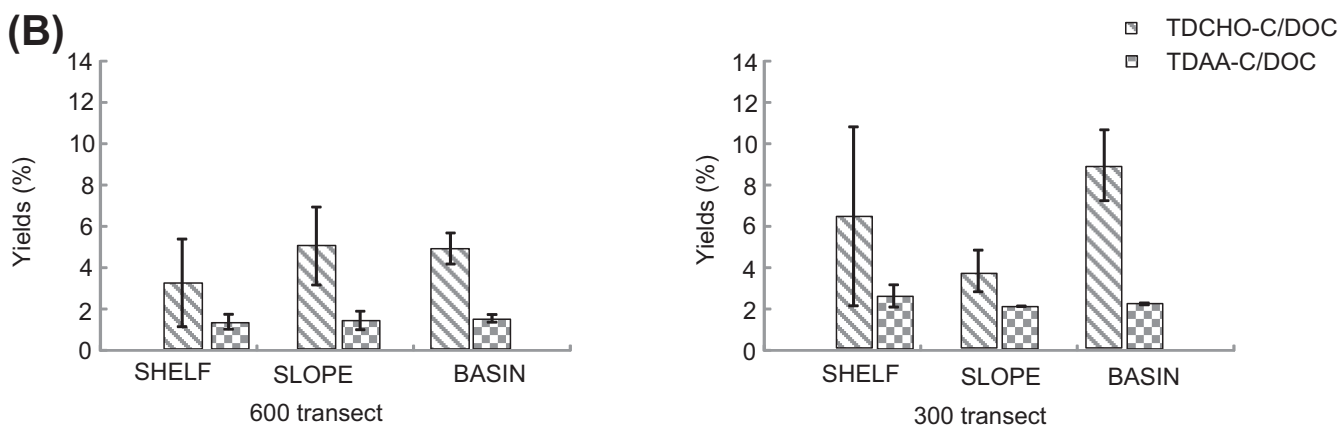

Fig. 5. (A) Average distributions of DOC and TCHO-C concentrations and (B) yields of sugars and amino acids calculated for the surface waters ( 0 - $80 \mathrm{~m}$ ) of the shelf, slope, and basin areas for the 600 (stations 697, 695, 690, 680, 670, 660, and 620) and 300 (stations 398, 394, 380, 360, 340, and 320; Fig. 1) transects. Stations 697 and 398 are typical of the Mackenzie River mouth. TDAA-yields are from Shen et al. (2012). 


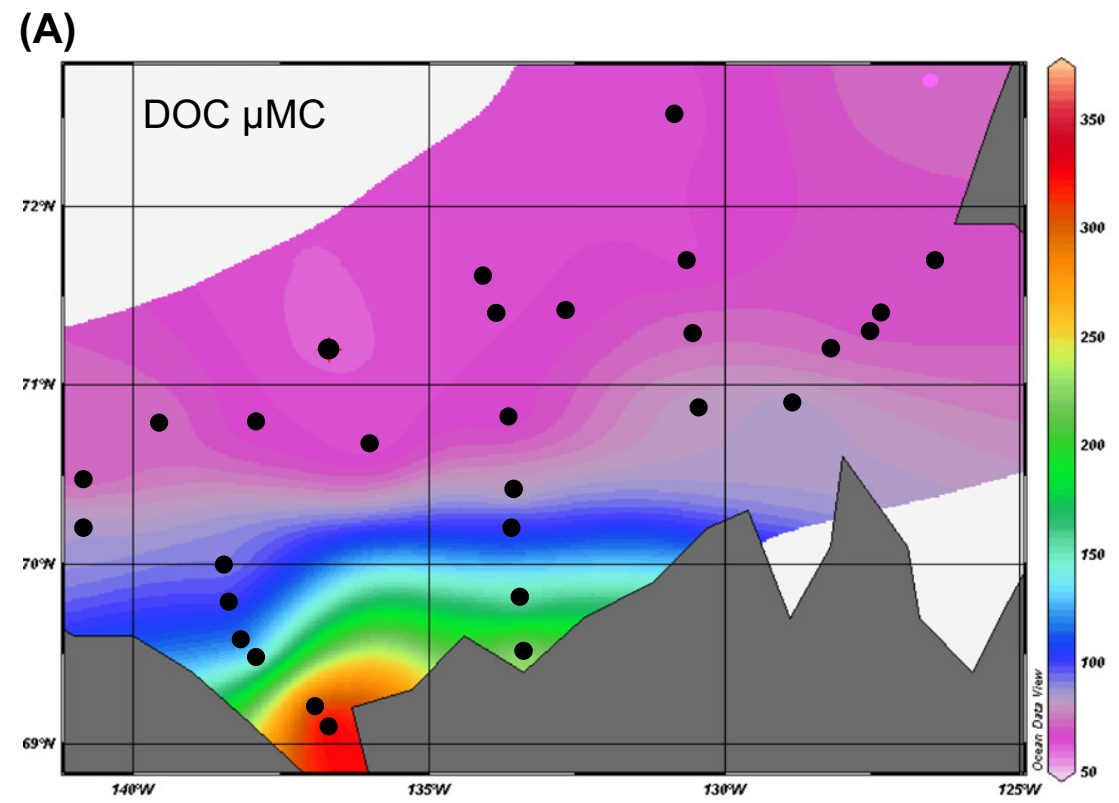

(B)

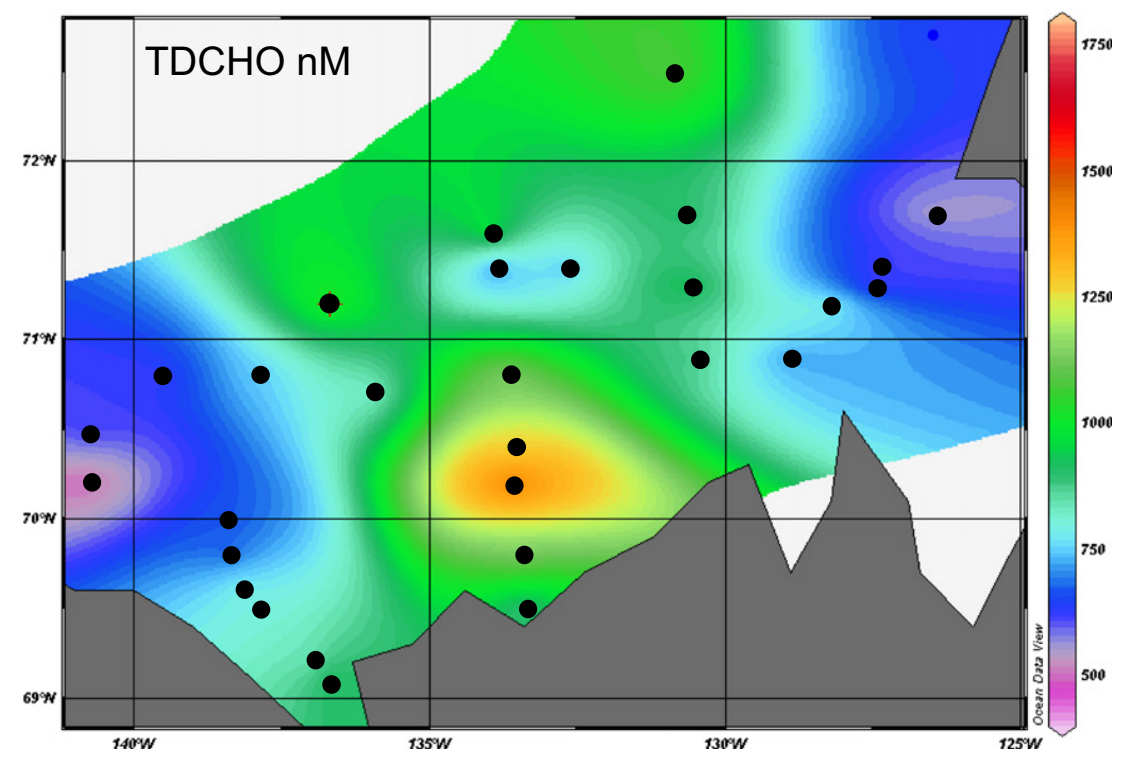

Fig. 6. Distributions of (A) DOC and (B) TCHO in the upper surface layer of the studied area. DOC and TCHO concentrations are mean values between 0 and $80 \mathrm{~m}$. The black dots correspond to the sampling stations shown in Fig. 1.

of TDCHO in the area, and perhaps they could explain the accumulation of carbohydrates in the eastern part of the river mouth transect (transect 300). Alternatively, the accumulation of carbohydrates in the 300 transect might be related to other local sources. For example, sea ice is known to contain dissolved carbohydrate extracellular polymeric substances produced by microalgae and bacteria (Underwood et al., 2013). According to the previous authors, these dissolved carbohydrates could account for as much as $36 \%$ of the sea-ice DOC concentration, which could be released following summer ice melt into the DOM. In any event, our results are further supported by similar TDCHO distribution from the shelf to the basin surface waters $(0-80 \mathrm{~m})$ recorded along the adjacent 200 (TDCHO range: 973-1025 nM) and 400 (TDCHO range: $1070-1130 \mathrm{nM}$ ) transects relative to the 300 transect (TDCHO range: $1186-1190 \mathrm{nM}$; Figs. 1 and 6B). TDCHO values below $80-\mathrm{m}$ depth were in agreement with our above observations and were higher for the 300 transect (TDCHO range: 505-632 nM) than for the 600 transect (TDCHO range: 326-509 $\mathrm{nM}$ ), indicating again an excess of carbohydrates in the eastern sector of the studied area.

Finally, it is worth noting that TDCHO concentrations were higher in the sector $130-135^{\circ} \mathrm{W}$ compared with adjacent sectors $\left(135-140^{\circ} \mathrm{W}\right.$ and $125-130^{\circ} \mathrm{W}$; Fig. $6 \mathrm{~B}$ ), which agrees well with the high bacterial carbon demand $(\mathrm{BCD})$ to PP ratios $(\mathrm{BCD} / \mathrm{PP})$ recorded in the same sector (e.g., $130-135^{\circ} \mathrm{W}$; Ortega-Retuerta et al., 2012). These results further indicate that in this particular area of the eastern Mackenzie margin, although net heterotrophic, labile organic compounds as generally assumed to be the carbohydrates do not seem to disappear, but rather they accumulate in the surface waters. Previous experimental and field-based work at the BATS site has also demonstrated that total neutral carbohydrates can resist degradation on at least monthly timescales (Goldberg et al., 2009). This feature might reflect differences in the 
production and/or consumption of these compounds within this area, while external inputs of organic matter containing carbohydrates might also be important.

Overall, and in contrast with DOC and amino acids, TDCHO concentrations in the surface waters $(0-80 \mathrm{~m})$ in the Beaufort Sea Mackenzie margin did not exhibit drastic changes from the shelf (TDCHO = $965 \pm 361 \mathrm{nM}, \mathrm{n}=24)$ to the basin area (TDCHO $=900 \pm 321 \mathrm{nM}$, $\mathrm{n}=10$ ). However, patches of higher and lower concentrations were observed in the studied area (Table 1; Fig. 6B). This further indicates an accumulation of TDCHO in the Mackenzie River plume and the broader continental margin, which is probably related with slow cycling of TDCHO in the surface waters. TDCHO concentrations did not correlate with low salinities, typical of the Mackenzie River influence, in the surface waters of the shelf area. This further implies that the Mackenzie River is not the only source of TDCHO in the area, and that perhaps in situ production of TDCHO via PP or other external terrestrial inputs of organic matter (see above) might be equally important.

\subsection{Bioavailability of TDCHO}

The freshness of the DOM in the studied area has been evaluated using TDCHO-yields (Skoog and Benner, 1997; Amon et al., 2001; Amon and Benner, 2003). According to Amon and Benner (2003), TDCHOyields $\geq 4 \%$ are typical of freshly derived phytoplankton DOM, whereas TDCHO-yields $\leq 2.5 \%$ are indicative of old DOM or terrestrial DOM derived from rivers. Our results agree with these features because we found very low values ( $2 \%$ ) in the inshore stations (697; 398), whereas values $\geq 6 \%$ were recorded for the surface waters of the slope and basin areas (Table 1). Interestingly, the highest TDCHO-yields recorded in this study were along the 300 transect (range 5-15\%) in the surface waters (Fig. 5B). However, these high values of TDCHO-yields should not necessarily be regarded as fresh material, because TDCHO concentrations were relatively constant along this transect (1190-1186 nM; see above), whereas DOC decreased rapidly, resulting in such high values of TDCHO-yields. On the other hand, TDCHO-yields showed a rapid decrease with depth together with TDCHO concentrations and DOC, which further indicates a selective removal of carbohydrates from the DOM pool (Table 1).

The amount of the semi-labile DOC in surface waters was calculated after subtraction of deep seawater DOC values from surface values and divided by DOC. Our results showed that the semi-labile DOC accounted for $10-40 \%$ and $20-50 \%$ of DOC in the slope and basin areas, respectively indicating a gradient of "lability" from the shelf to the basin area. Although not all of the carbohydrate are "labile compounds", the above result is in general agreement with our TDCHO-yields (Table 1), which were also increased from the shelf to the basin area. These results suggest a different diagenetic state/freshness between the shelf and basin area based on the carbohydrate component of DOM.

Similar to total dissolved amino acids (TDAA), TDCHO concentrations also exhibited significant relationships with $\mathrm{BP}$, although they were weaker relative to TDAA (Ortega-Retuerta et al., 2012), highlighting the importance of carbohydrates in the semi-labile carbon pool. Notably, stronger relationships were estimated for the basin $\left(R^{2}=0.3595\right.$, $\mathrm{n}=11, \mathrm{p}<0.05)$ and slope areas $\left(\mathrm{R}^{2}=0.2273, \mathrm{n}=26, \mathrm{p}<0.05\right)$, whereas the relationship was not significant for the shelf area $\left(R^{2}=\right.$ $0.0145, \mathrm{n}=22, \mathrm{p}=0.57$ ). The lack of correlation between BP and carbohydrates in the surface waters of the shelf area confirms our above findings, indicating that most of the carbohydrate in the shelf area is of "recalcitrant" nature, whereas in the offshore stations, TDCHO are a mixture of "recalcitrant" and semi-labile organic matter produced in situ. This result is the opposite to that for amino acids where the high TDAA-yields recorded in the shelf area (1-1.5\%) are indicative of an in situ source shelf-produced organic matter, rich in amino acids and poor in carbohydrates (Davis and Benner, 2005, 2007; Shen et al., 2012). Again, in contrast with TDCHO-yields (Fig. 5B), TDAA-yields decreased rapidly or remained constant in the surface waters of the shelf to the basin area, reaching values as low as $0.7 \%$, typical of recalcitrant DOM, as suggested by the previous authors. However, DOM in the surface waters of the basin also contains labile carbohydrates (see above) and as such, its degradation status cannot be evaluated accurately using only TDAA-yields as indicators. These results suggest that a combined yield of TDCHO plus TDAA might be more accurate for assessing the bioavailability of DOM in terms of its potential "labile" components. The sum of the amino acid and carbohydrate-yields accounted for 7-10\% of DOC in the surface waters with higher values recorded in the basin area (Table 1).

\subsection{Sources and fate of TDCHO in the Beaufort Sea Mackenzie margin}

Although carbohydrates are ubiquitous compounds in nature and may originate from several sources in coastal environments (autochthonous and allochthonous inputs), we assessed their possible origin using specific ratios, similar to previous studies (Cowie and Hedges, 1984; Guggenberger et al., 1994; da Cunha et al., 2002; Panagiotopoulos et al., 2012). For example, fucose and rhamnose are mainly found in microorganisms and bacteria (e.g., soil material), while arabinose and xylose are mostly produced by plants (Oades, 1984; Guggenberger et al., 1994). Therefore, the (Fuc. + Rha.)/(Ara. + Xyl.) ratio may be used to discriminate soil and/or bacterially derived organic matter (when the ratio is $>0.5-2$ ) versus plant-derived carbohydrates (when the ratio is $<0.5$ ). Our results showed that the (Fuc. + Rha.)/(Ara. + Xyl.) ratio was $\sim 0.7$ at the coastal inshore stations and that it decreased to 0.4 in the offshore stations (Fig. 7A, B). In addition, the (Fuc. + Rha.) percentage (calculated on a glucose-free basis) was exceptionally high in the surface waters of inshore stations 697, 695, 398, and 390 (Fig. 1), ranging from 15 to $30 \%$, which suggested a bacterial and/or soil source. This result corroborates the high $\mathrm{C} / \mathrm{N}$ ratios measured in these stations ( $\mathrm{C} / \mathrm{N}=19-33$; Fig. 6), typical of soil-derived DOM (Kaiser et al., 2004; Kawahigashi et al., 2006). This soil signature recorded in the Mackenzie shelf area reflects the route of the Mackenzie River through lakes and wetlands, which contribute $>50 \%$ of its water mass (Yi et al., 2010; Fichot et al., 2013).

Alternatively, these high C/N ratios (19-33) could reflect an average of local in situ planktonic DOM production (C/N 10-12) and terrestrial plant influence $(C / N>40)$ (Amon and Meon, 2004). A survey assessing the distribution of lignin phenols - typically produced by vascular plants - in the DOM of the major Arctic rivers demonstrated that the Mackenzie River was unique compared with other rivers in terms of its low lignin discharge ( $3.60 \mathrm{Gg} \mathrm{yr}^{-1}$ ) and lack of correlation between lignin and ${ }^{14} \mathrm{C}$ age (Amon et al., 2012). The authors explained this result in terms of the rapid removal of fresh vascular plant-derived organic matter from the DOM during freshet, absorption of fresh lignin-rich DOM onto suspended particulate matter, and the major influence of the wetlands and lakes on the DOM composition. Although, in our study we have not measured lignin phenols, the above findings are in agreement with our results, suggesting that DOM in the Mackenzie shelf has a more pronounced soil signature than terrestrial plant influence. This result is reinforced by the high (Fuc. + Rha.)\% values measured at the shelf stations implying a soil source, although these monosaccharides are also produced in smaller amounts by planktonic organisms (Cowie and Hedges, 1984). On the other hand, the $\mathrm{C} / \mathrm{N}$ ratios measured in the surface waters for the offshore slope and basin stations of the 300 transect varied from 11 to 12 , whereas those of the 600 transect were much higher, ranging from 16 to 18 (Fig. 7). Similar patterns were observed for the (Fuc. + Rha.)\% relative abundance, with lower values obtained from the 300 transect (3-5\%) possibly reflecting a planktonic source, and the higher values (7-9\%) for the 600 transect reflecting the influence of the Mackenzie River.

As indicated above, the high $\mathrm{C} / \mathrm{N}$ ratios together with high (Fuc. + Rha.)\% abundance are indicative of a soil-derived source. However, the (Fuc. + Rha.) $/($ Ara. + Xyl.) ratios of $~ 0.5$, recorded for the 600 transect, might also indicate a possible vascular plant contribution from the 


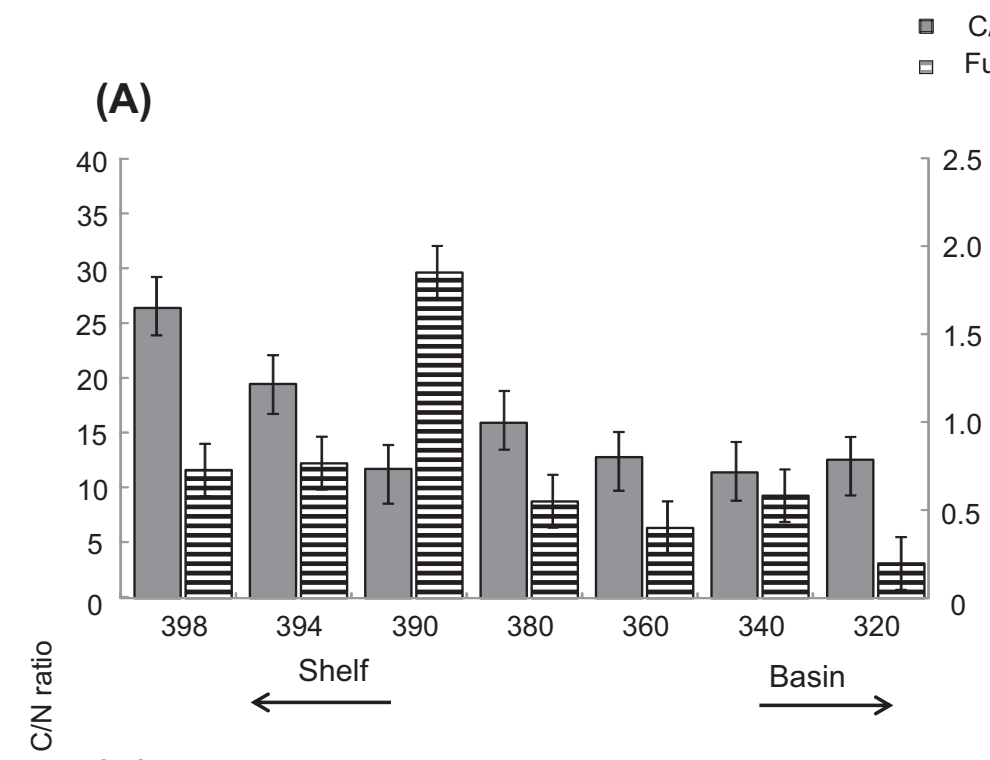

(B)

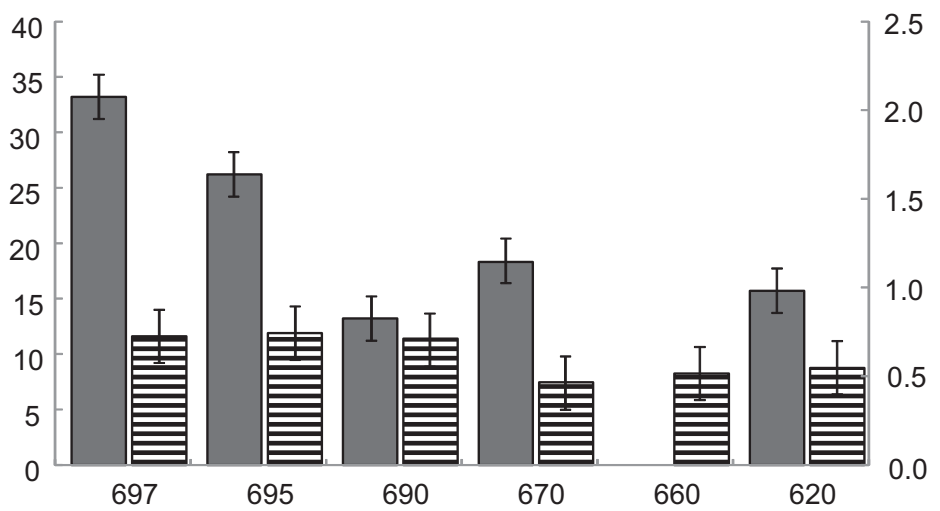

Stations

Fig. 7. C/N and (Fuc. + Rha.)/(Ara. + Xyl.) ratios for the (A) 300 and (B) 600 transects. The stations of each transect are also included (Fig. 1).

Mackenzie River (Fig. 7). Indeed, recent studies have reported the presence of $n$-alkanes and $n$-alkanols (Tolosa et al., 2013) as well as dehydroabietic acid (Rontani et al., 2014) on suspended organic matter and sediments during the same cruise, indicating a terrestrial plant source possibly derived from gymnosperms. This result is further supported by the low values Xyl.\% (13-17\%), typical of gymnosperm wood or tissues (Cowie and Hedges, 1984). However, it is important to note that this range of Xyl.\% values has also been recorded in the cell lysate from phytoplanktonic Emiliania huxleyi (Biersmith and Benner, 1998) and as such, an in situ autochthonous source of the carbohydrates cannot be excluded.

Previous investigations of the carbohydrate composition of DOM in the Mackenzie River have indicated that glucose accounts for between 24 and $28 \%$ of TDCHO, suggesting highly degraded organic matter (Opsahl and Benner, 1999; Engbrodt, 2001). Our results showed that our offshore and inshore Mackenzie stations (Fig. 1) did not follow this pattern, as we found high relative abundances of glucose $(\sim 50 \%$; Fig. 5) typical of an autochthonous source produced in situ (e.g., algae, phytoplankton; Biersmith and Benner, 1998; Hama and Yanagi, 2001), highlighting the productivity of the shelf of the Mackenzie margin. These results suggest that the carbohydrate component of the DOM in the Mackenzie margin appears to have a more pronounced autochthonous origin (based on the high relative abundance of glucose) with an important contribution from terrestrial sources, especially for the shelf stations (based on the high C/N ratios; Figs. 1 and 7). Given the current data, it is difficult to assess the possible contribution of the different sources of glucose to the DOM in the area and therefore, a more detailed analysis, including investigations of compound-specific isotopic measurements $\left(\delta^{13} \mathrm{C}\right)$ and lignin phenols, is warranted.

Finally, despite the high glucose\% typical of fresh material, the carbohydrate component of the DOM paradoxically does not seem to be removed (see above) from the shelf coastal waters, which leads to an accumulation of carbohydrates in surface waters. Although more data on the carbohydrate component of the DOM are required, the current results confirm the influence of both the relief of the studied area, which is characterized by a narrow continental shelf, and the anticyclonic circulation of the Beaufort gyre, which act to "trap" the surface waters.

\section{Summary and concluding remarks}

The objective of this study was to explore the TDCHO features in terms of their distribution, bioavailability, potential sources, and fate in the Beaufort Sea Mackenzie margin; an area of the Arctic Ocean sensitive to future climate change. Our results showed that TDCHO concentrations in the surface waters $(0-80 \mathrm{~m})$ of the Beaufort Sea margin, and in contrast to DOC and TDAA, did not appear to exhibit drastic changes from the shelf to the basin area, indicating an accumulation of TDCHO, 
perhaps related to their slow cycling in the surface waters. TDCHOyields in the surface waters were $6 \pm 2 \%$ and $8 \pm 3 \%$ for the shelf and basin stations, respectively, indicating a gradient of carbohydrate freshness from the inshore to offshore stations. Based on $\mathrm{C} / \mathrm{N}$ ratios and relative abundances of specific monosaccharides, we conclude that the shelf area of our study site is mostly affected by soil-derived matter delivered via the Mackenzie River, with possible contributions from mainly gymnosperm terrestrial plants. Overall, the carbohydrate component of the DOM of the Mackenzie margin appears to have a more pronounced autochthonous origin (based on the high relative abundance of glucose), with an important contribution from terrestrial sources, especially for the shelf stations. These results suggest a uniform distribution of TDCHO carbohydrates within the study area, with occasional patches of higher or lower concentrations.

Future research within the area could include compound-specific isotopic measurements for monosaccharides $\left(\delta^{13} \mathrm{C}\right)$ in ultrafiltrated DOM, as well as in POM and sediments, to better assess their origins and to evaluate more accurately their distributions. Furthermore, combined analysis of carbohydrates and lignin phenols might also provide valuable information about their possible terrestrial sources. Finally, there is a lack of data on the seasonal variability of the DOM composition of the Mackenzie River and its subsequent influence to the broader shelf area. Such information would help in the assessment of the future evolution of the system.

\section{Acknowledgments}

This research was funded by the French National Research Agency under the grant MALINA (contract number ANR-BLANC08-1_310980), French LEFE-CYBER and CNES programs, and European Space Agency. We thank the captain and crew of the Canadian icebreaker Amundsen for excellent service at sea, as well as M. Babin (leader of the MALINA project). This work was carried out in the framework of the transverse axis DEBAT (DEgradation Biotique et Abiotique de la maTière organique en milieu marin: processus et interactions) of the MIO. The authors gratefully acknowledge J. Para, and A. Viret for analytical assistance and field assistance, as well as P. Raimbault for primary production and $\mathrm{C} / \mathrm{N}$ data. We also thank J.-F. Rontani, $\mathrm{M}$. Tedetti, and the two anonymous referees for their helpful comments and valuable advice. C.P. received support from the PACA region (MANDARINE project, grant number 2008-10372) and the Aix Marseille University (ORANGE project, FI-2011)

\section{References}

Amon, R.M.W., Benner, R., 2003. Combined neutral sugar as indicators of the diagenetic state of dissolved organic matter in the Arctic Ocean. Deep-Sea Res. I 50,151-169.

Amon, R.M.W., Meon, B., 2004. The biogeochemistry of dissolved organic matter and nutrients in two large Arctic estuaries and potential implications for our understanding of the Arctic Ocean system. Mar. Chem. 92, 311-330.

Amon, R.M.W., Fitznar, H.P., Benner, R., 2001. Linkages among the bioreactivity, chemical composition, and diagenetic state of marine dissolved organic matter. Limnol. Oceanogr. 46, 287-297.

Amon, R.M.W., Rinehart, A.J., Duan, S., Louchouarn, P., Prokushkin, A., Guggenberger, G., Bauch, D., Stedmon, C. Raymond, P.A. Holmes, R.M. McClelland, JW. Peterson, B. Walker, S.A., Zhulidov, A.V., 2012. Dissolved organic matter sources in large Arctic rivers. Geochim. Cosmochim. Acta 94, 217-237.

Anderson, L.G., 2002. DOC in the Arctic. In: Hansell, D.A., Carlson, C.A. (Eds.), Biogeochemistry of Marine Dissolved Organic Matter. Academic Press, pp. 665-683.

Benner, R., Benitez-Nelson, B., Kaiser, K., Amon, R.M.W., 2004. Export of young terrigenous dissolved organic carbon from rivers to the Arctic Ocean. Geophys. Res. Lett. 31, L05305. http://dx.doi.org/10.1029/2003GL019251.

Biersmith, A., Benner, R., 1998. Carbohydrates in phytoplankton and freshly produced dissolved organic matter. Mar. Chem. 63, 131-144.

Borch, N.H., Kirchman, D.L., 1997. Concentration and composition of dissolved combined neutral sugars (polysaccharides) in seawater determined by HPLC-PAD. Mar. Chem. 57, 85-95.

Carmack, E.C., Wassmann, P., 2006. Food webs and physical-biological coupling on panArctic shelves: unifying concepts and comprehensive perspectives. Prog. Oceanogr. 71, 446-477. http://dx.doi.org/10.1016/j.pocean.2006.10.004.

Carmack, E.C., Macdonald, R.W., Jasper, S., 2004. Phytoplankton productivity on the Canadian Shelf of the Beaufort Sea. Mar. Ecol. Prog. Ser. 277, 37-50.
Cottrell, M.T., Malmstrom, R.R., Hill, V., Parker, A.E., Kirchman, D.L., 2006. The metabolic balance between autotrophy and heterotrophy in the western Arctic Ocean. DeepSea Res. I 53, 1831-1844. http://dx.doi.org/10.1016/j.dsr.2006.08.010.

Cowie, G.L., Hedges, J.I., 1984. Carbohydrate sources in a coastal marine environment. Geochim. Cosmochim. Acta 48, 2075-2087.

da Cunha, L.C., Serve, L., Blazi, J.L., 2002. Neutral sugars as biomarkers in the particulate organic matter of a French Mediterranean river. Org. Geochem. 33, 953-964.

Davis, J., Benner, R., 2005. Seasonal trends in the abundance, composition and bioavailability of particulate and dissolved organic matter in the Chukchi/Beaufort Seas and western Canada Basin. Deep-Sea Res. II 52, 3396-3410.

Davis, J., Benner, R., 2007. Quantitative estimates of labile and semilabile dissolved organic carbon in the western Arctic Ocean: a molecular approach. Limnol. Oceanogr. 52, 2434-2444.

de Leeuw, J.W., Largeau, C., 1993. A review of macromolecular organic compounds that comprise living organisms and their role in kerogen, coal, and petroleum formation. In: Engel, M.H., Macko, S.A. (Eds.), Organic Geochemistry Principles and Applications. Plenum Publishing, New York, pp. 23-72.

Dittmar, T., Kattner, G., 2003. The biogeochemistry of the river and shelf ecosystem of the Arctic Ocean: a review. Mar. Chem. 83, 103-120.

Drenzek, N.J., Montluçon, D.B., Yunker, M.B., Macdonald, R.W., Eglinton, T.I., 2007. Constraints on the origin of sedimentary organic carbon in the Beaufort Sea from coupled molecular ${ }^{13} \mathrm{C}$ and ${ }^{14} \mathrm{C}$ measurements. Mar. Chem. 103, 146-162.

Emmerton, C.A., Lesack, L.F.W., Vincent, W.F., 2008. Mackenzie River nutrient delivery to the Arctic Ocean and effects of the Mackenzie Delta during open water conditions. Glob. Biogeochem. Cycles 22, GB1024. http://dx.doi.org/10.1029/2006GB002856.

Engbrodt, R., 2001. Biogeochemistry of Dissolved Carbohydrates in the Arctic, (Ph.D Thesis).

Engbrodt, R., Kattner, G., 2005. On the biogeochemistry of dissolved carbohydrates in the Greenland Sea (Arctic). Org. Geochem. 36, 937-948.

Engel, A., Handel, N., 2011. A novel protocol for determining the concentration and composition of sugars in particulate and in high molecular weight dissolved organic matter (HMW-DOM) in seawater. Mar. Chem. 127, 180-191.

Fernandes, M.B., Sicre, M.-A., 2000. The importance of terrestrial organic carbon inputs on Kara Sea shelves as revealed by n-alkanes, OC and $\delta^{13} \mathrm{C}$ values. Org. Geochem. 31 363-374.

Fichot, C.G., Kaiser, K., Hooker, S.B., Amon, R.M.W., Babin, M., Bélanger, S., Walker, S.A., Benner, R, 2013. Pan-Arctic distributions of continental runoff in the Arctic Ocean. Sci. Rep. http://dx.doi.org/10.1038/srep01053.

Forest, A., Babin, M., Stemmann, L., Picheral, M., Sampei, M., Fortier, L., Gratton, Y., Bélanger, S., Devred, E., Sahlin, J., Doxaran, D., Joux, F., Ortega-Retueta, E., Martin, J. Jeffrey, W.H., Gasser, B., Miquel, J.C., 2013. Ecosystem function and particle flux dynamics across the Mackenzie Shelf (Beaufort Sea, Arctic Ocean): an integrative study of spatial variability and biophysical forcings. Biogeosciences 10, 2833-2866.

Fransson, A., Chierici, M., Anderson, L.C., Bussmann, I., Kattner, G., Jones, E.P., Swift, J.H., 2001. The importance of shelf processes for the modification of chemical constituents in the waters of the Eurasian Arctic Ocean: implication for carbon fluxes. Cont. Shelf Res. 21, 225-242.

Goldberg, S.J., Carlson, C.A., Hansell, D.A., Nelson, N.B., Siegel, D.A., 2009. Temporal dynamics of dissolved combined neutral sugars and the quality of dissolved organic matter in the northwestern Sargasso Sea. Deep-Sea Res. I 56, 672-685.

Goñi, M.A., Yunker, M.B., Macdonald, R.W., Eglinton, T.I., 2000. Distribution and sources of organic biomarkers in Arctic sediments from the Mackenzie River and Mackenzie shelf. Mar. Chem. 71, 23-51.

Grebmeier, J.M., Cooper, L.W., Feder, H.M., Sirenko, B.I., 2006. Ecosystem dynamics of the Pacific-influenced northern Bering and Chukchi seas in the Amerasian Arctic. Prog. Oceanogr. 71, 331-361.

Grigoriev, M.N., Rachold, V., Hubberten, H.W. Schirrmeister, L, 2004. Organic carbon input to the Arctic Seas trough coastal erosion. In: Stein, R., Macdonald, R.W. (Eds.), The Organic Carbon Cycle in the Arctic Ocean. Springer, Berlin, pp. 41-45.

Guéguen, C., Guo, L., Tanaka, N., 2005. Distributions and characteristics of colored dissolved organic matter in the western Arctic Ocean. Cont. Shelf Res. 25, 1195-1207.

Guggenberger, G., Christensen, B.T., Zech, W., 1994. Land use effects on the composition of organic matter in particle size separates of soil: I. Lignin and carbohydrate signature. Eur. J. Soil Sci. 45, 449-458

Hama, T., Yanagi, K., 2001. Production and neutral aldose composition of dissolved carbohydrates excreted by natural marine phytoplankton populations. Limnol. Oceanogr 46, 1945-1955.

Hansell, D.A., Kadko, D., Bates, N.R., 2004. Degradation of terrigenous dissolved organic carbon in the western Arctic Ocean. Science 304, 858-861.

Hill, V., Cota, G., 2005. Spatial patterns of primary production on the shelf, slope and basin of the Western Arctic in 2002 . Deep-Sea Res. II 52, 3344-3354

Holmes, R.M., McClelland, J.W., Peterson, B.J., Tank, S.E., Bulygina, E., Eglinton, T.I., Gordeev, V.V., Gurtovaya, T.Y., Raymond, P.A., Repeta, D.J., Staples, R., Striegl, R.G., Zhulidov, A.V Zimov, S.A., 2012. Seasonal and annual fluxes of nutrients and organic matter from large rivers to the Arctic Ocean and surrounding seas. Estuar. Coast. 35, 369-382.

Kaiser, K., Guggenberger, G. Haumaier, L, 2004. Changes in dissolved lignin derived phenols, neutral sugars, uronic acids, and amino sugars with depth in forested Haplic Arenosols and Rendzic Leptosols. Biogeochemistry 70, 135-151.

Kawahigashi, M., Kaiser, K., Rodionov, A., Guggenberger, G., 2006. Sorption of dissolved organic matter by mineral soils of the Siberian forest tundra. Glob. Change Biol. 12, 1868-1877.

Kirchman, D.L., Meon, B., Ducklow, H.W., Carlson, C.A., Hansell, D.A., Steward, G., 2001. Glucose fluxes and concentrations of dissolved combined sugars (polysaccharides) in the Ross Sea and Polar Front Zone, Antarctica. Deep-Sea Res. II 48, 4179-4197.

Kirchman, D.L., Hill, V., Cottrell, M.T., Gradinger, R., Malmstrom, R.R., Parker, A., 2009. Standing stocks, production, and respiration of phytoplankton and heterotrophic bacteria in the western Arctic Ocean. Deep-Sea Res. II 56, 1237-1248. 
Lalande, C., Forest, A., Barber, D.G., Gratton, Y., Fortier, L., 2009. Variability in the annua cycle of vertical particulate organic carbon export on Arctic shelves: contrasting the Laptev Sea, Northern Baffin Bay and the Beaufort Sea. Cont. Shelf Res. 29, 2157-2165. http://dx.doi.org/10.1016/j.csr.2009.08.009.

Lara, R.J., Rachold, V., Kattner, G., Hubberten, H.W., Guggenberger, G., Skoog, A., Thomas, D.N., 1998. Dissolved organic matter and nutrients in the Lena River, Siberian Arctic. Characteristics and distribution. Mar. Chem. 59, 301-309.

Lavoie, D., McDonald, R.W., Denman, K.L., 2009. Primary productivity and export fluxes on the Canadian shelf of the Beaufort Sea: a modelling study. J. Mar. Syst. 75, 17-32.

Letscher, R.T., Hansell, D.A., Kadko, D., 2011. Rapid removal of terrigenous dissolved organic carbon over the Eurasian shelves of the Arctic Ocean. Mar. Chem. 123, 78-87.

Long, Z.X., Perrie, W., 2013. Impacts of climate change on fresh water content and sea surface height in the Beaufort Sea. Ocean Model. 71, 127-139.

Macdonald, R., Yu, Y., 2006. The Mackenzie Estuary of the Arctic Ocean. In: Wangersky, P.J. (Ed.), The Handbook of Environmental Chemistry. Springer, Berlin, pp. 91-120.

Macdonald, R.W., Solomon, S.M., Cranston, R.E., Welch, H.E., Yunker, M.B., Gobeil, C., 1998 A sediment and organic carbon budget for the Canadian Beaufort Shelf. Mar. Geol. $144,255-273$.

Macdonald, R.W., Carmack, E.C., McLaughlin, F.A., Falkner, K.K., Swift, J.H., 1999. Connec tions among ice, runoff and atmospheric forcing in the Beaufort Gyre. Geophys. Res. Lett. 26, 2223-2226.

Macdonald, R.W., McLaughlin, F.A., Carmack, E.C., 2002. Fresh water and its source during the SHEBA drift in the Canada Basin of the Arctic Ocean. Deep-Sea Res. I 49, $1769-1785$.

Mathis, J.T., Hansell, D.A., Bates, N.R., 2005. Strong hydrographic controls on spatial and seasonal variability of dissolved organic carbon in the Chukchi Sea. Deep-Sea Res. II 52, 3245-3258.

Mathis, J.T., Pickart, R.S., Hansell, D.A., Kadko, D., Bates, N.R., 2007. Eddy transport of organic carbon and nutrients from the Chukchi Shelf: impact on the upper halocline of the western Arctic Ocean. J. Geophys. Res. Oceans 112, C05011. http://dx.doi.org/ 10.1029/2006JC003899.

Matsuoka, A., Bricaud, A., Benner, R., Para, J., Sempéré, R., Prieur, L., Bélanger, S., Babin, M. 2012. Tracing the transport of colored dissolved organic matter in water masses of the southern Beaufort Sea: relationship with hydrographic characteristics. Biogeosciences 9, 925-940.

Mopper, K., Schultz, C., Chevolot, L., Germain, C., Revuelta, R., Dawson, R., 1992. Determination of sugars in unconcentrated seawater and other natural waters by liquid chromatography. Environ. Sci. Technol. 26, 133-137.

Murrell, M.C., Hollibaugh, J.T., 2000. Distribution and composition of dissolved and particulate organic matter in northern San Francisco bay during low flow conditions. Estuar. Coast. Shelf Sci. 51, 75-90.

O'Brien, M.C., Macdonald, R.W., Melling, H., Iseki, K., 2006. Particle fluxes and geochemistry on the Canadian Beaufort Shelf: implications for sediment transport and deposition. Cont. Shelf Res. 26, 41-81. http://dx.doi.org/10.1016/j.csr.2005.09.007.

Oades, J.M., 1984. Soil organic matter ad structural stability: mechanisms and implications for management. Plant Soil 76, 319-337.

Opsahl, S., Benner, R., 1999. Characterization of carbohydrates during early diagenesis of five vascular plant tissues. Org. Geochem. 30, 83-94.

Ortega-Retuerta, E., Jeffrey, W.H., Babin, M., Bélanger, S., Benner, R., Marie, D., Matsuoka A., Raimbault, P., Joux, F., 2012. Carbon fluxes in the Canadian Arctic: patterns and drivers of bacterial abundance, production and respiration on the Beaufort Sea margin. Biogeosciences 9, 3679-3692.

Osburn, C.L., O'Sullivan, D.W., Boyd, T.J., 2009. Increases in the longwave photobleaching of chromophoric dissolved organic matter in coastal waters. Limnol. Oceanogr. 54 , 145-159.

Panagiotopoulos, C., Sempéré, R., 2005. Analytical methods for the determination of sugars in marine environments: a historical perspective and future directions. Limnol. Oceanogr. Methods 3, 419-454.

Panagiotopoulos, C., Sempéré, R., Lafont, R., Kerhervé, P., 2001. Sub-ambient temperature effects on separation of monosaccharides by HPAEC-PAD. Application to marine chemistry. J. Chromatogr. A 920, 13-22.

Panagiotopoulos, C., Sempéré, R., Para, J., Raimbault, P., Rabouille, C., Charrière, B., 2012 The composition and flux of particulate and dissolved carbohydrates from the Rhône River into the Mediterranean Sea. Biogeosciences 9, 1827-1844.

Panagiotopoulos, C., Repeta, D.J., Mathieu, L., Rontani, J.-F., Sempéré, R., 2013. Molecular level characterization of methyl sugars in marine high molecular weight dissolved organic matter. Mar. Chem. 154, 34-45.

Para, J., Charrière, B., Matsuoka, A., Miller, W.L., Rontani, J.-F., Sempéré, R., 2013. UV/PAR radiation and DOM properties in surface coastal waters of the Canadian shelf of the Beaufort Sea during summer 2009. Biogeosciences 10, 2761-2774.

Peterson, B.J., Holmes, R.M., McClelland, J.W., Vörösmarty, C.J., Lammers, R.B., Shiklomanov, A.I., Shiklomanov, I.A., Rahmstorf, S., 2002. Increasing river discharge to the Arctic Ocean. Science 298, 2171-2173.

Peulvé, S., Sicre, M.-A., Saliot, A., De-Leeuw, J.W., Baas, M., 1996. Molecular characterization of suspended and sedimentary organic matter in an Arctic delta. Limnol. Oceanogr. 41 , 488-497.
Rachold, V., Eicken, H., Gordeev, V.V., Grigoriev, M.N., Hubberten, H.-W., Lisitzin, A.P. Shevchenko, V.P., Schirrmeister, L., 2004. Modern terrigenous organic carbon input to the Arctic Ocean. In: Stein, R., Macdonald, R.W. (Eds.), The Organic Carbon Cycle in the Arctic Ocean. Springer, New York, pp. 33-35.

Rawlins, M.A., Steele, M., Holland, M.M., Adam, J.C. Cherry, J.E., Francis, J.A., Groisman, P.Y Hinzman, L.D., Huntington, T.G., Kane, D.L., Kimball, J.S, Kwok, R. Lammers, R.B., Lee, C.M., Lettenmaier, D.P., McDonald, K.C., Podest, E., Pundsack, J.W., Rudels, B., Serreze, M.C., Shiklomanov, A., Skagseth, Ø., Troy, T.J., Vöeröesmarty, C.J., Wensnahan, M., Wood, E.F., Woodgate, R., Yang, D., Zhang, K., Zhang, T., 2010. Analysis of the Arctic system for freshwater cycle intensification: observations and expectations. J. Clim. 23, 5715-5737.

Raymond, P.A., McClelland, J.W., Holmes, R.M., Zhulidov, A.V., 2007. Flux and age of dissolved organic carbon exported to the Arctic Ocean: a carbon isotopic study of the five largest Arctic rivers. Glob. Biogeochem. Cycles 21, GB4011. http://dx.doi. org/10.1029/2007GB002934.

Rich, J.H., Ducklow, H.W., Kirchman, D.L., 1996. Concentrations and uptake of neutra monosaccharides along $140^{\circ} \mathrm{W}$ in the Equatorial Pacific: contribution of glucose to heterotrophic bacterial activity and the DOM flux. Limnol. Oceanogr. 41, 595-604.

Rich, J., Kirchman, D.L., Gosselin, M., Sherr, E., Sherr, B., 1997. High bacterial production, uptake and concentration of dissolved organic matter in the Central Arctic Ocean. Deep-Sea Res. II 44, 1645-1664.

Rontani, J.-F., Charrière, B., Petit, M., Vaultier, F., Heipieper, H.J., Link, H., Chaillou, G., Sempéré, R., 2012a. Degradation state of organic matter in surface sediments from the Southern Beaufort Sea: a lipid approach. Biogeosciences 9, 3513-3530.

Rontani, J.-F., Charrière, B., Forest, A., Heussner, S., Vaultier, F., Petit, M., Desault, N., Fortier L., Sempéré, R., 2012b. Intense photooxidative degradation of planktonic and bacteria lipids in sinking particles collected with sediment traps across the Canadian Beaufort Shelf (Arctic Ocean). Biogeosciences 9, 4787-4802.

Rontani, J.-F., Charrière, B., Sempéré, R., Doxaran, D., Vaultier, F., Vonk, J.E., Volkman, J.K. 2014. Degradation of sterols and terrestrial organic matter in waters of the Mackenzie Shelf, Canadian Arctic. Org. Geochem. 75, 61-73.

Sempéré, R., Tedetti, M., Panagiotopoulos, C., Charrière, B., van Wambeke, F., 2008. Distribution and bacterial availability of dissolved neutral sugars in the South East Pacific Biogeosciences 5, 1165-1173.

Shen, Y., Fichot, C.G., Benner, R., 2012. Dissolved organic matter composition and bioavailability reflect ecosystem productivity in the Western Arctic Ocean. Biogeosciences 9 , 4993-5005.

Skoog, A., Benner, R., 1997. Aldoses in various size fractions of marine organic matter: implications for carbon cycling. Limnol. Oceanogr. 42, 1803-1813.

Skoog, A., Lara, R.J., Kattner, G., 2001. Spring-summer cycling of DOC and inorganic N in a highly seasonal system encompassing the Northeast water Polynya, 1993. Deep-Sea Res. I 48, 2613-2629.

Sohrin, R. Sempéré, R. 2005. Seasonal variation in total organic carbon in the Northeast Atlantic in 2000-2001. J. Geophys. Res. 110, C10S90. http://dx.doi.org/10.1029/ 2004JC002731.

Stroeve, J.C., Serreze, M.C., Fetterer, F., Arbetter, T., Meier, W., Maslanik, J., Knowles, K., 2005. Tracking the Arctic's shrinking ice cover: another extreme September minimum in 2004. Geophys. Res. Lett. 32, L04501. http://dx.doi.org/10.1029/2004GL021810.

Tolosa, I., Fiorini, S., Gasser, B., Martin, J., Miquel, J.-C., 2013. Carbon sources in suspended particles and surface sediments from the Beaufort Sea revealed by molecular lipid biomarkers and compound-specific isotope analysis. Biogeosciences 10, 2081-2087.

Underwood, G., Aslam, S.N., Michel, C., Niemi, A., Norman, L, Meiners, K.M., LaybournParry, J. Paterson, H., Thomas, D.N. 2013. Broad scale predictability of carbohydrates and exopolymers in Antarctic and Arctic sea ice. PNAS http://dx.doi.org/10.1073/ pnas.1302870110.

Unger, D., Gaye-haake, B., Neumann, K., Gebhardt, A.C., Ittekkot, V., 2005. Biogeochemistry of suspended and sedimentary material in the $\mathrm{Ob}$ and Yenisei rivers and Kara Sea; amino acids and amino sugars. Cont. Shelf Res. 25, 437-460.

van Dongen, B.E., Zenkac, Z., Gustafsson, Ö., 2008. Differential transport and degradation of bulk organic carbon and specific terrestrial biomarkers in the surface waters of a sub-arctic brackish bay mixing zone. Mar. Chem. 112, 203-214

Wang, D., Henrichs, S., Guo, L., 2006. Distributions of nutrients, dissolved organic carbon and carbohydrates in the western Arctic Ocean. Cont. Shelf Res. 26, 1654-1667.

Wheeler, P.A., Watkins, J.M., Hansing, R.L., 1997. Nutrients, organic carbon and organic nitrogen in the upper water column of the Arctic Ocean: implications for the sources of dissolved organic carbon. Deep-Sea Res. II 44, 1571-1592.

Yi, Y., Gibson, J.J., Hélie, J., Dick, T.A., 2010. Synoptic and time series stable isotope surveys of the Mackenzie River from Great Slave Lake to the Arctic Ocean, 2003-2006. J. Hydrol. 383, 223-232.

Zou, L., Sun, M.Y., Guo, L.D., 2006. Temporal variations of organic carbon inputs into the upper Yukon River: evidence from fatty acids and their stable carbon isotopic compositions in dissolved, colloidal and particulate phases. Org. Geochem. 37, 944-956. 